\title{
UnPACKING AnCIENT IsRaEAL
}

Book Title:

Ancient Israel: What do we know and how do we know it?

\section{Book Cover:}

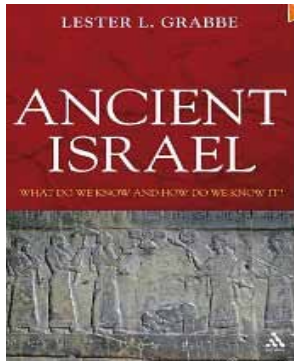

Author:

Lester L. Grabbe

\section{ISBN:}

978-0-5670-3254-6

\section{Publisher:}

T \& T Clark, Michigan,

2007, pp. 306, \$26.65

*Book price at time of Review

Review Title:

Unpacking Ancient Israeal

\section{Reviewer:}

Izak (Sakkie) J.J. Spangenberg ${ }^{1}$

\section{Affiliation:}

${ }^{1}$ Departement Old

Testament and Ancient

Near Eastern Studies,

University of South Africa,

South Africa

email:

spangijj@unisa.ac.za

\section{Postal address:}

Department of Old

Testament \& Ancient

Near Eastern Studies,

University of South Africa,

PO Box 392, Pretoria 0003 ,

South Africa

How to cite this book review: Spangenberg, I.J.J., 2010,

'Unpacking Ancient

Israeal', HTS Teologiese

Studies/Theological Studies

66(1), Art. \#989, 1 page.

DOI: 10.4102/hts.v66i1.989

\section{This review is available}

at:

http://www.hts.org.za

(c) 2010. The Authors. Licensee: OpenJournals Publishing. This work

is licensed under the

Creative Commons

Attribution License.
The book's title reminded me of the title of William Dever's book, What did the Biblical writers know and when did they know it? What archaeology can tell us about the reality of ancient Israel (2001). Before reading it, I could not but wonder whether Grabbe's book is meant to be an improvement on what Dever has written. Why the similarity as far as the title is concerned? However, after reading the book, I realised that this book should not be judged by its title alone! Grabbe not only reflects on what Dever has written but on what a large number of other scholars have recently published on the history of Israel.

The book consists of four main parts:

- an introduction in which the principles and methods of historical investigation are discussed (33 pages)

- a large middle piece in which the principles and methods are applied to four historical periods in the history of Israel (176 pages)

- a short conclusion that summarises the results of the application (7 pages)

- an extensive bibliography (54 pages). I regard the bibliography as part and parcel of the book since there is much to be gained from taking note of the publications he refers to. From the bibliography it is evident that he has read extensively and that he takes note of what a large number of scholars have written.

Grabbe has produced a good and solid piece of research on the history of Israel. Each of the four sections of the second part (the middle piece) has the following subsections:

- sources

- analysis

- synthesis.

Firstly, he discusses the sources that are available for a specific historical period before he analyses and weighs them. It is only in the third subsection that he synthesises and paints a picture of the specific period. The historical periods that he discusses are:

- Middle and Late Bronze Ages (2000-1300 BCE)

- Late Bronze II to Iron IIA (1300-900 BCE)

- Iron IIB (900-720 BCE)

- Iron IIC (720-539 BCE)

All serious students of the Old Testament should read and study the introduction to this book. Grabbe steers clear of classifying scholars as either 'minimalists' or 'maximalists'. He argues that one should take note of recent studies in historiography and apply the same principles and methods of the study of Israel's history, rather than labelling scholars.

The introduction reminded me of the late Ferdinand Deist (1944-1997) and his contribution to the study of the Old Testament in South Africa. No South African scholar prior to him or even after him had such a keen interest in the history of Israel and wrote so extensively on the subject of historiography. Grabbe's book stands in this same tradition. It introduces students to study and discuss the subject, but it is also suitable for postgraduate studies. For any student or scholar interested in the study of Israel's history and religion, this book has much to offer.

We have come a long way since John Bright's book, A history of Israel (1972) and Martin Noth's book,The history of Israel (1972) and need some direction through the thickets of recent historical studies. I only wish that the other three historical periods had a table similar to the one which Grabbe supplies at the end of the first historical period (cf. pp. 62-63).

Although the book is not meant as a history of Israel proper it lays a solid foundation for such a publication. I sincerely hope that Grabbe will soon write such a book. This one has whetted my appetite. It is worth buying, reading and discussing and I recommend it without reservation. 